\title{
Chemokine and Chemokine Receptor Gene Polymorphism in Tunisian Hemodialysis Patients with HCV Infection
}

Leila Ksiaa Cheikh Rouhou ${ }^{1 *}$, Yousr Lakhoua Gorgi ${ }^{1}$, Hajer Aounallah Skhiri ${ }^{2}$, Houda Aouadi ${ }^{1}$, Salwa Jendoubi-Ayed ${ }^{1}$, Imen Sfar ${ }^{1}$, Khaled Ayed ${ }^{1}$, Taieb Ben Abdallah ${ }^{1}$

1. Immunology Research Laboratory of Kidney Transplantation and Immunopathology (Laboratoire de Recherche: LR03SP01), Charles Nicolle Hospital, Tunisia.

2. National Public Health Institute, Tunisia.

\begin{abstract}
Introduction: Our aim was to investigate the possibility of a significant relationship between chemokines and chemokine receptor genes polymorphisms and the spontaneous clearance or the persistence of $\mathrm{HCV}$ infection.
\end{abstract}

Methods: A total of 96 hemodialysis (HD) patients infected with HCV were classified into two groups: G1 included 73 patients with persistently positive HCV-RNA and G2 included 23 HD patients who have spontaneously eliminated the virus. The control group consisted of 170 healthy blood donors. All subjects were genotyped for CCR5 $\triangle 32$, CCR5 (-59029) A/G, CCR2 (64Ile) and MCP-1(-2518) A/G gene polymorphisms.

Results: Our results showed statistically significant increased frequencies of the CCR2 (64Ile) and the (-59029) CCR5 A alleles in patients infected with HCV (22.1\% and $35.9 \%$ ) compared to G1 (24.3\% and 40.6\%) and compared to controls $(14.4 \%$ and $20 \%)$. We also observed a lower frequency of the MCP-1 G allele and a greater frequency of the CCR $5 \Delta 32$ variant in G2 $(15.2 \%$ and $6.5 \%)$ compared to $\mathrm{G} 1(22.6 \%$ and $1.4 \%)$ that was not statistically significant. However, adjustment for known covariates (age, gender and HCV genotypes) didn't confirm the results of univariate analysis.

Conclusion: In conclusion, our study suggests a possible role for some of the studied chemokines polymorphisms in the spontaneous clearance or persistence of $\mathrm{HCV}$ infection in Tunisian population. These results should be further investigated by a prospective cohort studies and large population-based studies.

\footnotetext{
* Corresponding Author: Dr. Ksiaa Cheikhrouhou Leila, Immunology Laboratory; Charles Nicolle Hospital, Bd 9 Avril, 1006, Tunis, Tunisia; Email: ksiaaleila@yahoo.fr
}

Keywords: Chemokines; Receptors; Hepatitis C virus; Spontaneous Clearance; Polymorphisms.

This study was supported by a grant from the Tunisian Immunology Research Laboratory (LR03SP01) Fund. The authors declared no conflict of interest

\section{Introduction}

Hepatitis $\mathrm{C}$ virus (HCV) is the major cause of post transfusion hepatitis. $\mathrm{HCV}$ infection becomes chronic in about $80 \%$ of infected individuals and often leads to serious consequences, including liver cirrhosis and hepatocellular carcinoma (HCC) $[1,2]$. Only $20 \%$ of infected subjects clear the virus spontaneously [3]. Studies of early HCV infection suggest that a vigorous CD4+ T cells response is associated with viral clearance [4-6]. In contrast, patients developing a chronic infection show a predominant Th2 response [7-9]. Interplay between chemokines and their receptors is considered crucial for transmigration of lymphocytes and monocytes from the circulation to the liver portal area of inflammation during viral hepatitis, including HCV induced hepatitis. Differences in chemokine receptor expression between Th1 and Th2 cells might explain the regulating $\mathrm{T}$ helper cell polarization and their selective recruitment to liver tissue $[10,11]$. Among these inflammatory molecules, monocyte chemoattractant protein-1 (MCP-1) with the corresponding chemokine receptors CCR2 and CCR5, specific receptor for pro-inflammatory chemokines: Rantes, MIP- $1 \alpha$ and MIP-1 $\beta$, are likely to be responsible for mononuclear cell accumulation in progressive of liver injury. Several allelic variants of these proteins have been shown to be important in the pathogenesis viral infection, either by modulating virological response or by influencing the severity of liver injury [12-14]. 
A bi-allelic G/A polymorphism at position -2518 of the MPC-1 gene, relative to the major transcriptional start site, has been described and was shown to influence the level of MCP-1 production in response to inflammatory stimuli [15].

CCR5 and CCR2 are two of a cluster of six chemokine receptor genes mapped to $3 \mathrm{p} 21$. A substitution mutation resulting in a valine (Val) to isoleucine (Ile) designed CCR2 (64Ile), a 32-bp deletion in the CCR5 gene leading to a non-functional protein and CCR5 promoter single nucleotide polymorphisms (SNP) were identified. Both CCR mutations have been implicated in the pathogenesis of human immunodeficiency virus (HIV) infection and the presence of the muted allele confers varying degree of anti-HIV protection that is reflected in slower disease progression [16]. Several studies have examined these polymorphisms in association with $\mathrm{HCV}$ and HIV infections [17-19].

The aim of this study was to investigate the distribution of the wild type and mutant alleles of MCP-1 -2518, CCR5- 32 , CCR5-59029 and CCR2 (64Ile) in HCV infected hemodialysis Tunisian patients in comparison with healthy controls. Furthermore, we have analyzed the association of particular genotypes with outcomes of HCV infection, in terms of viral clearance or viral persistence.

\section{Methods}

Subjects: This is a retrospective study which involved $96 \mathrm{HCV}$ infected individuals with confirmed antibody positivity to $\mathrm{HCV}$. They were negative for hepatitis B surface antigen (HBsAg) and HIV infection. All patients were dialyzed during 2004 at different hemodialysis (HD) centers (private and public) in various regions of Tunisia. They were divided into two groups. Group I (G1) included 73 patients with persistent $\mathrm{HCV}$ infection as assessed by two positive PCR tests for HCV-RNA separated by more than one year. Group II (G2) consisted of 23 subjects considered to have spontaneously recovered from $\mathrm{HCV}$ infection on the basis of two negative PCR tests for HCV-RNA one year apart. None of the patients had received treatment for $\mathrm{HCV}$ infection before entering the study. Data obtained from each patient at the HD center included age at diagnosis, gender and possible risk factors for HCV (such as blood transfusion, invasive procedures or intravenous drug abuse). These two groups of patients were comparable in viral characteristics and average duration on HD (Table-1). In addition, blood samples were obtained from 170 ethnical and geographically matched healthy individuals who tested negative for HBsAg, HIV-Ab and HCV-Ab. These 170 subjects served as controls. The study was approved by the ethics committee of Charles Nicolle Hospital (Tunis, Tunisia) and all participants gave informed consent to participate in the study.

HCV RNA detection: HCV-RNA in serum was detected by reverse transcriptase PCR (Inno-Lipa HCV II, Innogenetics Belgium) according to the manufacturer's instructions. Patients who were HCV-PCR positive on the initial assessment and became consistently HCV-PCR negative were classified in G2.

Typing HCV: HCV genotypes were determined by means of inverse hybridization using specific oligonucleotide probes assay (HCV Genotype Assay Lipa, Innogenetics Belgium) according to the manufacturer's instructions.

DNA Extraction: Blood samples were collected on EDTA, and DNA was isolated by the Salting-Out method reported by Miller et al [20].

MCP-1 promoter genotyping: The identification of polymorphism was carried out using PCR, followed by a restriction fragment length polymorphism (RFLP) assay, using PvuII site which is introduced by the presence of the $\mathrm{G}$ nucleotide. The regulatory region of the MCP1 gene (-1817 to -2746) was amplified by PCR resulting in 930 bp fragment. Primers used were 5'CCGAGATGTTCCCAGCCAG-3' (forward) and 5'-CTGCTTTGCTTGTGCCTCTT-3' (reverse). $1 \mu \mathrm{l}$ of genomic DNA ( 100ng) were added to $19 \mu \mathrm{l}$ of amplification buffer containing $11 \mu \mathrm{l}$ of $\mathrm{H} 2 \mathrm{O}, 4 \mu \mathrm{l}$ of $5 \mathrm{x}$ PCR buffer, $1.6 \mu \mathrm{l}$ of $\mathrm{MgCl} 2(2 \mathrm{mM}), 0.4 \mu \mathrm{l}$ of dNTPs $(0.2 \mathrm{mM}), 0.1 \mu \mathrm{l}$ of Taq DNA polymerase $(0.5 \mathrm{U})$ and $5 \mu \mathrm{M}$ of each forward and reverse primers. PCR was run for 40 cycles using the following temperature profile: denaturation at $94^{\circ} \mathrm{C}$ for $60 \mathrm{~s}$, annealing at $55^{\circ} \mathrm{C}$ for $60 \mathrm{~s}$, extension at $72^{\circ} \mathrm{C}$ for $1 \mathrm{~min}$ and $30 \mathrm{~s}$, followed by a single final extension step at $72^{\circ} \mathrm{C}$ for $10 \mathrm{~min} .4 \mu \mathrm{l}$ of the PCR products were digested with $5 \mathrm{U}$ of Pvullin 10x buffer and $\mathrm{H} 2 \mathrm{O}$ up to a final volume of $20 \mu \mathrm{l}$ at $37^{\circ} \mathrm{C}$ for $2 \mathrm{~h}$ and $30 \mathrm{~min}$. The resulting products were separated by gelelectrophoresis in $1.5 \%$ agarose gel. Samples showing only a 930bp were assigned as AA, samples showing two bands of $708 \mathrm{bp}$ and $222 \mathrm{bp}$ were considered GG and samples showing three bands 930, 708 and 222bp were typed AG.

CCR5-59029genotyping: CCR5-59029genomic variants were detected by using RFLP-PCR. The presence of the $\mathrm{G}$ nucleotide at position -59029 of the CCR5 gene creates a recognitionsite for theBspI286Ienzyme. Primersusedwere 5'-CCCGTGAGCCCATAGTTAAAACTC-3' (forward) and 5'-TCACAGGGCTTTTCAACAGTAAGG-3' (reverse). $2 \mu$ l of genomic DNA ( $100 \mathrm{ng}$ ) were added to $18 \mu \mathrm{l}$ of amplification buffer containing $11.8 \mu \mathrm{l}$ of $\mathrm{H} 2 \mathrm{O}$, $4 \mu \mathrm{l}$ of $5 \mathrm{x}$ PCR buffer, $1.2 \mu \mathrm{l}$ of $\mathrm{MgCl} 2(1.5 \mathrm{mM}), 0.35 \mu \mathrm{l}$ 
of dNTPs $(0.175 \mathrm{mM}), 0.1 \mu \mathrm{l}$ of Taq DNA polymerase $(0.5 \mathrm{U}), 10 \mu \mathrm{M}$ of each forward and reverse primers. PCR was run for 35 cycles using the following temperature profile: a single initial denaturation at $94^{\circ} \mathrm{C}$ for $4 \mathrm{~min}$, denaturation at $94^{\circ} \mathrm{C}$ for $30 \mathrm{~s}$, annealing at $55^{\circ} \mathrm{C}$ for $45 \mathrm{~s}$, extension at $72^{\circ} \mathrm{C}$ for $1 \mathrm{~min}$, followed by a single final extension step at $72^{\circ} \mathrm{C}$ for $7 \mathrm{~min} .5 \mu \mathrm{l}$ of the PCR products were digested with $3 \mathrm{U}$ of BspI286I in $10 \mathrm{x}$ buffer and $\mathrm{H} 2 \mathrm{O}$ up to a final volume of $20 \mu 1$ at $37^{\circ} \mathrm{C}$ for 1 night. The resulting products were separated by gel-electrophoresis in $2 \%$ agarose gel. Samples showing only a $130 \mathrm{bp}$ were assigned as GG, samples showing only $258 \mathrm{bp}$ band were considered AA and heterozygote have both bands.

CCR2 (64Ile) genotyping: For characterization of the CCR2 polymorphism, sequence specific primer PCR was used (SSP-PCR). The first primer was specific for the wild type allele sequence. The second primer was specific for the sequence of the mutant allele. In the case of homozygous wild type individual $(+/+)$, the product was observed only in the first reaction. In the case of a homozygous mutant individual (64Ile/64Ile), the product was detected only in the second reaction. When the typed proband was heterozygous (+/64Ile), the product were detected in both the wild and the mutant specific reaction. Primers used were CCR2 440 5'-GTGGGCAACATGCTGGTCA-3', CCR2441 5'CCCAAAGACCCACTCATTTG-3', and CCR2 442 5'-GTGGGCAACATGCTGGTCG-3', $1 \mu \mathrm{l}$ of genomic DNA ( $\sim 100$ ng) was added to $14 \mu 1$ of amplification buffer containing $7.5 \mu \mathrm{l}$ of $\mathrm{H} 2 \mathrm{O}, 3 \mu \mathrm{l}$ of $5 \mathrm{x}$ PCR buffer, $1.2 \mu \mathrm{l}$ of $\operatorname{MgCl} 2(2 \mathrm{mM}), 0.3 \mu \mathrm{l}$ of dNTPs $(0.2 \mathrm{mM}), 0.05 \mu \mathrm{l}$ of Taq DNA polymerase $(0.25 \mathrm{U})$ and $5 \mu \mathrm{M}$ of each primer. PCR was run for 5 cycles using a single initial denaturation at $94^{\circ} \mathrm{C}$ for $1 \mathrm{~min}, 5$ cycles of denaturation at $96^{\circ} \mathrm{C}$ for $25 \mathrm{~s}$, annealing at $65^{\circ} \mathrm{C}$ for $50 \mathrm{~s}$, extension at $72^{\circ} \mathrm{C}$ for $45 \mathrm{~s}, 21$ cycles of denaturation at $96^{\circ} \mathrm{C}$ for $25 \mathrm{~s}$, annealing at $70^{\circ} \mathrm{C}$ for $45 \mathrm{~s}$, extension at $72^{\circ} \mathrm{C}$ for $45 \mathrm{~s}$, and 4 cycles of denaturation at $96^{\circ} \mathrm{C}$ for $25 \mathrm{~s}$, annealing at $55^{\circ} \mathrm{C}$ for $60 \mathrm{~s}$, extension at $72^{\circ} \mathrm{C}$ for $2 \mathrm{~min}$.

CCR5 $\Delta 32$ genotyping: CCR5 $\Delta 32$ genotype was determined by sizing PCR amplicons that include the entire region of the deletion. PCR was conducted in $15 \mu 1$ reaction containing $0.5 \mu \mathrm{l}$ of genomic DNA (50ng), $5 \mu \mathrm{M}$ of each primer, $0.25 \mu \mathrm{l}$ of dNTPs $(0.175 \mathrm{Mm}), 0.9 \mu \mathrm{l}$ of $\mathrm{MgCl} 2(1.5 \mathrm{mM}), 3 \mu \mathrm{l}$ of $5 x$ PCR buffer and $0.1 \mu \mathrm{l}$ of Taq DNA polymerase $(0.5 \mathrm{U})$. Thermocycling procedure consisted of initial denaturation at $94^{\circ} \mathrm{C}$ for $4 \mathrm{~min}$, followed by 35 cycles of $94^{\circ} \mathrm{C}$ for $30 \mathrm{~s}, 52^{\circ} \mathrm{C}$ for $45 \mathrm{~s}, 72^{\circ} \mathrm{C}$ for $7 \mathrm{~min}$; amplicons were visualized in $2 \%$ agarose gel. The sense primer was 5'-TGTTTGCGTCTCTCCCAG-3', and antisense was 5'-CACAGCCCTGTGCCTCTT-3', which result in a $233 \mathrm{bp}$ product for the wild type amplicon $(+/+)$ and $201 \mathrm{bp}$ for the deletion product $(\Delta 32 / \Delta 32)$.
Statistical methods: Genotypes and alleles frequencies were calculated using Epi-stat program (version 6; center for disease control and prevention [CDC], Atlanta, GA). Statistical comparisons between different groups of patients and controls was conducted by the $\chi^{2}$ test calculated on $2 \times 2$ contingency tables. Fisher exact test was used when an expected cell value was less than 5 . P value $<0.05$ was considered statistically significant. The strength of the association between genotypes or alleles in each group was estimated by calculating of the odds ratios $(\mathrm{OR})$ and $95 \%$ confidence intervals $(\mathrm{CI})$ using the same software. Logistic regression models were built with clearance of HCV infection (RNA-HCV negative) as the response variable to estimate adjusted ORs.

\section{Results}

\section{Epidemiological characteristics}

Clinical and virological characteristics are summarized in Table-1. Our results showed that $1 \mathrm{~b}$ genotype was the predominant genotype among G1 (64.4\%) and G2 $(70 \%)$. The prevalence of risk factors was similar in both groups. None of the patients was an intravenous drug user. Ninety patients $(93.7 \%)$ had history indicating risk of exposure to HCV due to blood transfusion $(56.3 \%)$ or due to surgical or medical invasive procedures $(37.5 \%)$. No significant differences were found in the distribution according to regions, private versus public nature of the HD centers or the duration of HD between the two groups of patients.

\section{Genetic polymorphisms}

All analyzed allele frequencies and genotype distributions were in Hardy-Weinberg equilibrium both in patients and controls. All polymorphism frequencies are described below and summarized in Table-2.

MCP-1 gene polymorphism: Comparison of allele frequencies in patients infected with $\mathrm{HCV}$ and controls did not reveal significant difference for the MCP-1 gene polymorphism. Nevertheless, the frequency of genotype GG was lower in patients $(5.2 \%)$ than in controls (17\%). Regarding the two groups of HD patients, there was an increased frequency of the G allele in G1 (22.6\%) compared with G2 (15.2\%) but the difference did not reach statistical significance.

CCR2 (64Ile) gene polymorphism: Significant differences were found between $\mathrm{HCV}$ infected patients and controls regarding the CCR2 (64Ile) gene polymorphism. The frequency of the $+/+$ genotype was significantly higher in controls $(73.5 \%)$ compared to HCV infected patients as a whole $(60 \%)$ and to $\mathrm{G} 1$ patients $(56.9 \%)[\mathrm{P}=0.03 ; \mathrm{OR}=1.9 ; \mathrm{CI} 95 \%=1.3-2.7$, and $\mathrm{P}=0.02 ; \mathrm{OR}=2.1, \mathrm{CI} 95 \%=1.1-3.9$ respectively]. 
Table 1: Clinical and virological characteristics of the study subjects

\begin{tabular}{lcc}
\hline Characteristics & G1 (n= 73) & G2 (n= 23) \\
\hline Gender ratio (Male/Female) & $33 / 40$ & $13 / 10$ \\
Mean age (years) & $58 \pm 13.08$ & $55.5 \pm 11.7$ \\
HCV genotype: $\mathrm{n}(\%)^{*}$ & & \\
1a & $2(2,6)$ & - \\
1b & $47(64.4)$ & $7(70 \%)$ \\
2a/2c & $7(9.2)$ & $1(10 \%)$ \\
4 & $14(18.4)$ & $2(20 \%)$ \\
1b/4 & $3(4)$ & - \\
Risk factors: $\mathrm{n}(\%)$ & & \\
Blood transfusion & $40(64.8)$ & $14(60.8)$ \\
Invasive procedure & $29(39.7)$ & $7(30.4)$ \\
Intravenous drug abuse & 0 & 0 \\
Regional distribution: $\mathrm{n}(\%)$ & & \\
Tunis (Capital region) & $62(84.9)$ & $23(100)$ \\
North & $10(13.7)$ & 0 \\
Central & 0 & 0 \\
$\quad$ South & $1(1.3)$ & 0 \\
HD in private sector: $\mathrm{n}(\%)$ & $64(87.7)$ & $18(78.26)$ \\
HD in public sector: $\mathrm{n}(\%)$ & $9(12.3 \%)$ & $5(21,7)$ \\
Mean duration on HD (months) & $158.1 \pm 58$ & $164 \pm 60.21$ \\
\hline & & \\
\hline & &
\end{tabular}

* HCV genotype was determined for only 10 patients in G2 who were HCV-RNA positive at baseline and spontaneously cleared HCV infection as suggested by two subsequent negative HCV-PCR detections one year apart.

On the other hand, the frequency of the +/64Ile genotype was significantly increased in the HCV infected patients group as a whole $(35.8 \%)$ and in $\mathrm{G} 1(37.5 \%)$ compared to controls $(24.1 \%)[\mathrm{P}=0.04 ; \mathrm{OR}=0.6$; CI 95\% $=0.3-1.0$; $\mathrm{P}=0.05 ; \mathrm{OR}=0.5 ; \mathrm{CI} 95 \%=0.3-1.0$ respectively $]$. The distribution of allele frequencies showed a significantly increased frequency of the 64Ile allele in HCV infected patients group $(22.1 \%)$ and in G1 $(24.3 \%)$ compared to controls $(14.4 \%)[\mathrm{P}=0.03 ; \mathrm{OR}=0.6$; CI 95\% $=0.4-1.0$ and $\mathrm{P}=0.09 ; \mathrm{OR}=0.5$; CI 95\% $=0.3-0.9$ respectively]. The comparison of these frequencies according to the evolution of HCV infection also revealed an increased frequency of the 64Ile allele in G1 $(24.3 \%)$ compared to G2 (15.2\%). However, this difference did not attain statistical significance.

CCR5-59029 gene polymorphism: The AACCR5-59029 genotype occurred more frequently among $\mathrm{HCV}$ infected patients and G1 compared to controls (35.9 and 40.6\% versus $20 \%)[\mathrm{P}=0.01 ; \mathrm{OR}=0.5$, CI $95 \%=0.3-0.8$ and $\mathrm{P}=0.002 ; \mathrm{OR}=0.4 ; \mathrm{CI} 95 \%=0.2-0.7$ respectively]. The frequency of the AG CCR5-59029 genotype was decreased in G1 compared with controls (36.2\% versus 52.4\%) $[\mathrm{P}=0.03, \mathrm{OR}=1.9, \mathrm{CI} 95 \%=1.1-3.6]$. Comparison of allele frequencies showed an increased frequency of the A allele in $\mathrm{HCV}$ infected patients group (56\%) and in G1 (58.7\%) compared to controls (46.2\%) $[\mathrm{P}=0.04 ; \mathrm{OR}=0.7 ; \mathrm{CI} 95 \%=0.5-1.0$ and $\mathrm{P}=0.02$; $\mathrm{OR}=0.6 ; \mathrm{CI} 95 \%=0.4-0.9$ respectively]. The comparison of these frequencies between the two groups of patients revealed a non significant higher frequency of the A allele in G1 (58.7\%) compared to G2 (47.8\%).

CCR5 $\Delta 32$ gene polymorphism: No significant differences in the genotype distribution or in allele frequencies were observed between patients infected with HCV and controls. No homozygous mutant CCR5 $\triangle 32$ subjects were detected in either the control group or G1. When transmission of these genetic variants was analyzed in the two groups of HD patients, the $\Delta 32$ variant was present at a greater frequency in $\mathrm{G} 2$ compared to G1 (6.5\% versus $1.4 \%)$, but this difference did not reach statistical significance.

Haplotype distribution: The allelic distribution of the CC-chemokine G MCP-1-2518 in combination with the corresponding chemokine receptor CCR2 (64Ile) did not differ significantly between patients and controls nor between G1 and G2. The same applies for the other haplotype associations: A(-59029)CCR5/64IleCCR2, A(-59029)CCR5/CCR5 $\Delta 32$ and CCR5 $\Delta 32 / 64 I l e C C R 2$ (Data not shown). After adjustment for age, gender and $\mathrm{HCV}$ genotypes as confounders, multivariate analysis did not reveal any statistical association for the alleles and genotype frequencies studied.

\section{Discussion}

This study showed an association between chemokines/ chemokine receptors and the outcomes of HCV infection in Tunisian HD patients. Our results suggested a possible role for the $-2518 \mathrm{MCP}-1 \mathrm{G}$ allele in the persistence of $\mathrm{HCV}$ infection. We speculate that individuals bearing $\mathrm{G}$ at position -2518 produce more $\mathrm{MCP}-1$ protein than individuals with A allele. In consequence, they could have a stronger inflammatory response with higher liver tissue damage. Our results, which indicated an increased prevalence of $-2518 \mathrm{G}$ allele in $\mathrm{G} 1$ patients compared to $\mathrm{G} 2$, are in agreement with this hypothesis. Indeed, Rovin et al reported that in vitro cells obtained from GG or GA subjects produce more MCP-1 molecule than those isolated from AA individuals [15]. On the other hand, $\mathrm{HCV}$ infected patients with the $-2518 \mathrm{MCP}-1 \mathrm{G}$ allele were reported to be more prone to hepatic inflammation and fibrosis [21]. The same higher level variant $G$ allele was suggested to contribute in the chronicity of HBV infection in Korean population [22]. However, the wide $\mathrm{CI}$ in many of our findings reflects the relatively small 
Table 1: MCP1, CCR2 and CCR5 genotype and allele frequencies in patients and controls

\begin{tabular}{|c|c|c|c|c|c|c|c|c|}
\hline \multirow[t]{2}{*}{ Polymorphisms } & \multicolumn{2}{|c|}{ Controls } & \multicolumn{2}{|c|}{ Total Patients } & \multicolumn{2}{|c|}{ G1 } & \multicolumn{2}{|c|}{ G2 } \\
\hline & $\mathrm{N}$ & $\%$ & $\mathrm{~N}$ & $\%$ & $\mathrm{~N}$ & $\%$ & $\mathrm{~N}$ & $\%$ \\
\hline \multicolumn{9}{|l|}{ MCP1-2518 } \\
\hline \multicolumn{9}{|l|}{ Genotype } \\
\hline AA & 91 & 53 & 61 & 63.5 & 45 & 61.6 & 16 & 69.6 \\
\hline $\mathrm{AG}$ & 67 & 40 & 30 & 31.3 & 23 & 31.5 & 7 & 30.4 \\
\hline GG & 12 & 17 & 5 & 5,2 & 5 & 6.9 & 0 & 0 \\
\hline \multicolumn{9}{|l|}{ Allele } \\
\hline A & 146 & 73.2 & 152 & 79.2 & 113 & 77.4 & 39 & 84.8 \\
\hline G & 91 & 26.8 & 40 & 20.8 & 33 & 22.6 & 7 & 15.2 \\
\hline \multicolumn{9}{|l|}{ CCR2 (64Ile)* } \\
\hline \multicolumn{9}{|l|}{ Genotype } \\
\hline$+/+^{+}$ & 125 & 73.5 & 57 & 60 & 41 & 56.9 & 16 & 69.6 \\
\hline$+/ 64 \mathrm{Ile}^{\ddagger}$ & 41 & 24.1 & 34 & 35.8 & 27 & 37.5 & 7 & 30.4 \\
\hline 641/64Ile & 4 & 2.4 & 4 & 4,2 & 4 & 55.6 & 0 & 0 \\
\hline \multicolumn{9}{|l|}{ Allele } \\
\hline+ & 291 & 85.6 & 148 & 77.9 & 109 & 75.7 & 39 & 84.8 \\
\hline $64 \mathrm{Ile}^{\S}$ & 49 & 14.4 & 42 & 22.1 & 35 & 24.3 & 7 & 15.2 \\
\hline \multicolumn{9}{|l|}{ CCR5 $\triangle 32$} \\
\hline \multicolumn{9}{|l|}{ Genotype } \\
\hline$+/+$ & 162 & 95.3 & 92 & 95.8 & 71 & 97.3 & 21 & 91.4 \\
\hline$+/ \Delta 32$ & 8 & 4.7 & 3 & 3.1 & 2 & 2.7 & 1 & 4.3 \\
\hline$\Delta 32 / \Delta 32$ & 0 & 0 & 1 & 1.1 & 0 & 0 & 1 & 4.3 \\
\hline \multicolumn{9}{|l|}{ Allele } \\
\hline+ & 332 & 97.6 & 187 & 97.4 & 144 & 98.6 & 43 & 93.5 \\
\hline$\Delta 32$ & 8 & 2.4 & 5 & 2.6 & 2 & 1.4 & 3 & 6.5 \\
\hline \multicolumn{9}{|l|}{ CCR5 $59029 \|$} \\
\hline \multicolumn{9}{|l|}{ Genotype } \\
\hline GG & 47 & 27.6 & 22 & 23.9 & 16 & 23.2 & 6 & 26 \\
\hline$A G^{\pi}$ & 89 & 52.4 & 37 & 40.2 & 25 & 36.2 & 12 & 52.2 \\
\hline $\mathrm{AA}^{* *}$ & 34 & 20 & 33 & 35.9 & 28 & 40.6 & 5 & 21.8 \\
\hline \multicolumn{9}{|l|}{ Allele } \\
\hline G & 183 & 53.8 & 81 & 44 & 57 & 41.3 & 24 & 52.2 \\
\hline $\mathrm{A}^{+\dagger}$ & 157 & 46.2 & 103 & 56 & 81 & 58.7 & 22 & 47.8 \\
\hline
\end{tabular}

* Only 95 total patients were tested for CCR2 (64Ile) (72 in G1 and 23 inG2).

$\dagger$ The homozygous $+/+$ CCR2 (64Ile) genotype was significantly higher in controls than in total patients group and in G1 HCV patients $[\mathrm{P}=0.0$; $\mathrm{OR}=1.9 ; \mathrm{CI} 95 \%=1.3-2.7$ and $\mathrm{P}=0.02 ; \mathrm{OR}=2.1, \mathrm{CI} 95 \%=1.1-3.9]$.

‡ The heterozygous +/64Ile CCR2 (64Ile) genotype was significantly increased in patients group and in G1 versus controls $[\mathrm{P}=0.043$; OR $=0.6$; CI 95\% $=0.3-1.02 ; \mathrm{P}=0.049 ; \mathrm{OR}=0.5 ; \mathrm{CI} 95 \%=0.3-1.0]$.

$\S$ Comparing CCR2 (64Ile) allele frequency in total patients group and G1with controls $[\mathrm{P}=0.03 ; \mathrm{OR}=0.6$; CI 95\% $=0.4-1.0$ and $\mathrm{P}=0.09$; $\mathrm{OR}=0.5 ;$ CI $95 \%=0.3-0.9]$.

|| Only 92 total patients were tested for (-59029)CCR5 A/G (69 in G1 and 23 in G2).

I The frequency of (-59029) CCR5AG genotype was significantly lower in G1 compared to controls [P $=0.03, \mathrm{OR}=1.9, \mathrm{CI} 95 \%=1.1-3.6]$.

** The frequency of (-59029) CCR5 AA genotype was significantly higher in total patients group and G1 compared to controls $[\mathrm{P}=0.01 ; \mathrm{OR}=0.5$, CI $95 \%=0.2-0.8$ and $\mathrm{P}=0.0017 ; \mathrm{OR}=0.4 ; \mathrm{CI} 95 \%=0.2-0.7]$.

$\dagger$ Comparing (-59029) CCR5 A allele frequency in total patients group and $\mathrm{G} 1$ with controls $[\mathrm{P}=0.04 ; \mathrm{OR}=0.7 ; \mathrm{CI} 95 \%=0.5-1.0$ and $\mathrm{P}=0.02$; $\mathrm{OR}=0.6$; CI $95 \%=0.4-0.9]$. 
number of patients, particularly in G2, with a consequent loss of statistical power. Another study that includes a greater number of patients who have spontaneously recovered from $\mathrm{HCV}$ infection would be required to verify this association. CCR2 signaling promotes Th1 development in infection models. Indeed, Traynor et al reported that CCR2 knock out mouse have $46 \%$ reduction in lymphocyte recruitment to sites of infection and inflammation and $80 \%$ reduction in CD4+T cells locally [23].Our study showed a significant association of the CCR2 (64Ile) allele with susceptibility to HCV infection and persistence of infection This variant was significantly increased in patients infected with $\mathrm{HCV}$ and in G1 compared to controls. In addition, this allele was more represented in persistent $\mathrm{HCV}$ infection group than in the clearance group. This is in agreement with results reported by Mascheretti et al, which showed that the CCR2 (64Ile) variant was under-represented in patients with spontaneous viral elimination compared to patients suffering from chronic infection, and that the frequency of the homozygous variant genotype was higher in patients who cleared the virus compared to both patients with persistent infection and controls in a German study [21]. This genetic variant has also been related to the onset of a variety of autoimmune/inflammatory diseases such as familial multiple sclerosis, pulmonary sarcoidosis, type 1 diabetes mellitus, asthma and inflammatory bowel disease [24]. In the majority of these studies, this genetic CCR2 variant has been found to be associated with a milder course and/or a reduced risk of developing diseases. In our study, the association between HCV persistence and CCR2 (64Ile) allele may reflect the same process with a reduction in the function of $\mathrm{CCR} 2$ in the $\mathrm{HCV}$ immune response and disease persistence. On the other hand, this polymorphism represents a conservative change in the first transmembrane domain of the protein. The receptor containing the variance has been shown to be expressed efficiently on the cell surface. Its signal transcription in response to MCP-1 binding and protein expression is not altered. This hypothesis could explain the defect of statistical association between haplotype G MCP1(-2518)/ CCR2(64Ile) and the outcome of HCV infection in our studied population. Previous studies have established that $\mathrm{A}(59029) \mathrm{CCR} 5$ allele had higher promoter activity than G(59029) and could regulate CCR5 gene expression [17, 25]. This observation is in accordance with our findings that reveal a significant association of the CCR5-59029 A allele with susceptibility to infection and progression to chronicity. Chang et al corroborate similar association between CCR5-59029 A allele and an increased risk of HBV infection in a Korean population [26].

In the CCR5 gene the most studied polymorphism was the 32 base pair deletion CCR5 $\triangle 32$ that creates a truncated protein that fails to reach the cell surface. Patients homozygous for this mutation cannot express CCR5 on the cell surface, whereas the heterozygous state results in decreased expression of the functional CCR5 protein [27]. In an Irish study, the heterozygote CCR5 $\triangle 32$ was associated with spontaneous clearance of HCV infection [19]. In agreement with this report, Hellier et al found an association between CCR $5 \Delta 32$ and reduced portal inflammation and milder fibrosis in a large European cohort [28]. Interestingly, CCR5 $\Delta 32$ carriers showed significantly reduced response rates to anti $\mathrm{HCV}$ interferon therapy $[29,30]$.

In accordance with cited studies, we observed a protective effect of this variant in our study. The $\Delta 32$ variant was more frequent in the cleared $\mathrm{HCV}$ infection group compared to the chronically infected group. The lack of statistical significance observed here might be due to the small size of our cohort, particularly the spontaneous clearance group.

Because the CCR2 and CCR5 genes are closely located on the chromosome $3 \mathrm{p} 21$, we suggest that the haplotype associations CCR5(-59029)A/CCR264Ile,CCR5(-59029) $\mathrm{A} / \mathrm{CCR} 5 \Delta 32$ and CCR5 $\Delta 32 / \mathrm{CCR} 264 \mathrm{Ile}$, combining the different genetic variants, may be important in the persistence of $\mathrm{HCV}$ infection.

Because of the small size of our cohort and the retrospective nature of the study, it should be considered an exploratory study and our results must be treated with caution. Future studies are needed to confirm these chemokine/chemokine receptor polymorphism associations with $\mathrm{HCV}$ infection progression and to further clarify their mechanism of action.

\section{Conclusion}

In conclusion, this study has attempted to elucidate the role of $\mathrm{CC}$ chemokines and their receptors in the persistence or clearance of $\mathrm{HCV}$ infection. Our data suggests that the CCR5(-59029) A, CCR2 (64Ile) and MCP-1(-2518) G allele profiles predispose to persistent $\mathrm{HCV}$ infection. They may be part of the spectrum of immunogenetic factors involved in chronic HCV disease in Tunisian population.

\section{Acknowledgment}

This study was supported by a grant for Tunisian Immunology Research Laboratory (LR03SP01) Fund.

\section{References}

1. Marcellin P. Conférence Internationale de consensus sur 1'hépatite C. Feuillets de biologie. 2000;248:27-32. 
2. Poynard T. Histoire naturelle de l'hépatite C. Feuillets de biologie. 2002;248:19-21.

3. Thimme R, Bukh J, Spangenberg HC, Wieland S, Pemberton J, Steiger C, Govindarajan S, Purcell RH, Chisari FV. Viral and immunological determinants of hepatitis $\mathrm{C}$ virus clearance, persistence, and disease. Proc Natl Acad Sci U S A. 2002 Nov 26;99(24):15661-8.

4. Cerny A, Chisari FV. Pathogenesis of chronic hepatitis $\mathrm{C}$ : immunological features of hepatic injury and viral persistence. Hepatology. 1999 Sep;30(3):595-601.

5. Chang KM, Thimme R, Melpolder JJ, Oldach D, Pemberton J, Moorhead-Loudis J, McHutchison JG, Alter HJ, Chisari FV. Differential CD4(+) and CD8(+) T-cell responsiveness in hepatitis $\mathrm{C}$ virus infection. Hepatology. 2001 Jan;33(1):267-76.

6. Missale G, Bertoni R, Lamonaca V, Valli A, Massari M, Mori C, Rumi MG, Houghton M, Fiaccadori F, Ferrari C. Different clinical behaviors of acute hepatitis $\mathrm{C}$ virus infection are associated with different vigor of the anti-viral cell-mediated immune response. J Clin Invest. 1996 Aug 1;98(3):706-14.

7. Diepolder HM, Zachoval R, Hoffmann RM, Wierenga EA, Santantonio T, Jung MC, Eichenlaub D, Pape GR. Possible mechanism involving T-lymphocyte response to non-structural protein 3 in viral clearance in acute hepatitis C virus infection. Lancet. 1995 Oct 14;346(8981):1006-7.

8. Dumoulin FL, Bach A, Leifeld L, El-Bakri M, Fischer HP, Sauerbruch T, Spengler U. Semiquantitative analysis of intrahepatic cytokine mRNAs in chronic hepatitis C. J Infect Dis. 1997 Mar;175(3):681-5.

9. Koziel MJ, Walker BD. Characteristics of the intrahepatic cytotoxic $\mathrm{T}$ lymphocyte response in chronic hepatitis C virus infection. Springer Semin Immunopathol. 1997;19(1):69-83.

10. Bonecchi R, Bianchi G, Bordignon PP, D’Ambrosio D, Lang R, Borsatti A, Sozzani S, Allavena P, Gray PA, Mantovani A, Sinigaglia F. Differential expression of chemokine receptors and chemotactic responsiveness of type 1 T helper cells (Th1s) and Th2s. J Exp Med. 1998 Jan 5;187(1):129-34.

11. Navratilova Z. Polymorphisms in CCL2\&CCL5 chemokines/chemokine receptors genes and their association with diseases. Biomed Pap Med Fac Univ Palacky Olomouc Czech Repub. 2006 Nov;150(2):191204.

12. Promrat K, Liang TJ. Chemokine systems and hepatitis $\mathrm{C}$ virus infection: is truth in the genes of the beholders?. Hepatology. 2003 Dec;38(6):1359-62.
13. Shields PL, Morland CM, Salmon M, Qin S, Hubscher SG, Adams DH. Chemokine and chemokine receptor interactions provide a mechanism for selective $\mathrm{T}$ cell recruitment to specific liver compartments within hepatitis C-infected liver. J Immunol. 1999 Dec 1;163(11):6236-43.

14. Wald O, Weiss ID, Galun E, Peled A. Chemokines in hepatitis $\mathrm{C}$ virus infection: pathogenesis, prognosis and therapeutics. Cytokine. 2007 Jul;39(1):50-62.

15. Rovin BH, Lu L, Saxena R. A novel polymorphism in the MCP-1 gene regulatory region that influences MCP-1 expression. Biochem Biophys Res Commun. 1999 Jun 7;259(2):344-8

16. Winkler C, Modi W, Smith MW, Nelson GW, Wu X, Carrington M, Dean M, Honjo T, Tashiro K, Yabe D, Buchbinder S, Vittinghoff E, Goedert JJ, O'Brien TR, Jacobson LP, Detels R, Donfield S, Willoughby A, Gomperts E, Vlahov D, Phair J, O’Brien SJ. Genetic restriction of AIDS pathogenesis by an SDF-1 chemokine gene variant. ALIVE Study, Hemophilia Growth and Development Study (HGDS), Multicenter AIDS Cohort Study (MACS), Multicenter Hemophilia Cohort Study (MHCS), San Francisco City Cohort (SFCC) .Science. 1998 Jan 16;279(5349):389-93.

17. Shieh B, Liau YE, Hsieh PS, Yan YP, Wang ST, $\mathrm{Li}$ C. Influence of nucleotide polymorphisms in the CCR2 gene and the CCR5 promoter on the expression of cell surface CCR5 and CXCR4. Int Immunol. 2000 Sep;12(9):1311-8.

18. Arenzana-Seisdedos F, Parmentier M. Genetics of resistance to HIV infection: Role of co-receptors and coreceptor ligands. Semin Immunol. 2006 Dec;18(6):387403.

19. Goulding C, McManus R, Murphy A, MacDonald G, Barrett S, Crowe J, Hegarty J, McKiernan S, Kelleher D. The CCR5-delta32 mutation: impact on disease outcome in individuals with hepatitis $\mathrm{C}$ infection from a single source. Gut. 2005 Aug;54(8):1157-61.

20. Miller SA, Dykes DD, Polesky HF. A simple salting out procedure for extracting DNA from human nucleated cells. Nucleic Acids Res. 1988 Feb 11;16(3):1215.

21. Mascheretti S, Hinrichsen H, Ross S, Buggisch P, Hampe J, Foelsch UR, Schreiber S. Genetic variants in the CCR gene cluster and spontaneous viral elimination in hepatitis C-infected patients. Clin Exp Immunol. 2004 May;136(2):328-33.

22. Park BL, Kim YJ, Cheong HS, Kim LH, Choi YH, Lee HS, Shin HD. Association of common promoter 
polymorphisms of MCP1 with hepatitis B virus clearance. Exp Mol Med. 2006 Dec 31;38(6):694-702.

23. Traynor TR, Herring AC, Dorf ME, Kuziel WA, Toews GB, Huffnagle GB. Differential roles of CC chemokine ligand $2 /$ monocyte chemotactic protein- 1 and CCR2 in the development of T1 immunity. J Immunol. 2002 May 1;168(9):4659-66.

24. Dong VM, McDermott DH, Abdi R. Chemokines and diseases. Eur J Dermatol. 2003 May-Jun;13(3):224-30.

25. McDermott DH, Zimmerman PA, Guignard F, Kleeberger CA, Leitman SF, Murphy PM. CCR5 promoter polymorphism and HIV-1 disease progression. Multicenter AIDS Cohort Study (MACS). Lancet. 1998 Sep 12;352(9131):866-70.

26. Chang HY, Ahn SH, Kim DY, Shin JS, Kim YS, Hong SP, Chung HJ, Kim SO, Yoo WD, Han KH. [Association between CCR5 promoter polymorphisms and hepatitis B virus infection]. Korean J Hepatol. 2005 Jun;11(2):11624. Korean.

27. Wu L, Paxton WA, Kassam N, Ruffing N, Rottman JB, Sullivan N, Choe H, Sodroski J, Newman W, Koup
RA, Mackay CR. CCR5 levels and expression pattern correlate with infectability by macrophage-tropic HIV-1, in vitro. J Exp Med. 1997 May 5;185(9):1681-91.

28. Hellier S, Frodsham AJ, Hennig BJ, Klenerman P, Knapp S, Ramaley P, Satsangi J, Wright M, Zhang L, Thomas HC, Thursz M, Hill AV. Association of genetic variants of the chemokine receptor CCR5 and its ligands, RANTES and MCP-2, with outcome of HCV infection. Hepatology. 2003 Dec;38(6):1468-76.

29. Glas J, Török HP, Simperl C, König A, Martin K, Schmidt F, Schaefer M, Schiemann U, Folwaczny C. The Delta 32 mutation of the chemokine-receptor 5 gene neither is correlated with chronic hepatitis $\mathrm{C}$ nor does it predict response to therapy with interferon-alpha and ribavirin. Clin Immunol. 2003 Jul;108(1):46-50.

30. Ahlenstiel G, Berg T, Woitas RP, Grünhage F, Iwan A, Hess L, Brackmann HH, Kupfer B, Schernick A, Sauerbruch T, Spengler U. Effects of the CCR5-Delta32 mutation on antiviral treatment in chronic hepatitis C. J Hepatol. 2003 Aug;39(2):245-52. 